\title{
BESPREKING VAN EEN AANTAL BEZWAREN \\ TEGEN DE VENNOOTSCHAPSBELASTING IN DE KOSTPRIJS
}

\author{
door Prof. A. M. van Rietschoten
}

In het nummer van november 1958 van dit blad is een artikel van mijn hand opgenomen over de rente in de kostprijs. Daarin werd door mij aan de orde gesteld of tot de kosten moet worden gerekend de rente over het doelmatig aangewend eigen vermogen, dan wel die rente, vermeerderd met de over die rente geheven belasting. Daarbij werd gedoeld op de vennootschapsbelasting. Hoewel het dan nog een vraag blijft, of hetzelf de probleem niet kan optreden, daar waar van vennootschapsbelasting geen sprake is, maar van inkomstenbelasting, komt het mij doelmatig voor de gedachtenwisseling voorlopig te beperken tot het verschijnsel, zoals het zich voordoet bij lichamen, die aan de vennootschapsbelasting onderworpen zijn. Aan het slot zal ik dan nog iets over de invloed van de inkomstenbelasting zeggen.

In de jaargang 1959 zijn drie artikelen opgenomen resp. van W. G. Brugge, $R$. de Koning en Drs. C. B. A. Kramers, die als reacties op het mijne zijn geschreven. In het Maandschrift Economie van april 1961 komt van de hand van H. H. M. Foppe een artikel voor: „De problematiek van de calculatie van rente en belasting in de kostprijs", welk stuk is geschreven naar aanleiding van hetzelfde artikel.

Het komt mij daarom gewenst voor van wederwoord te dienen waar dat past.

De belangrijkste bezwaren zijn naar voren gebracht door Brugge, daarin bijgevallen door Kramers. Het is noodzakelijk daar eerst aandacht aan te besteden.

Er wordt in zijn beschouwing van uitgegaan, dat het vraagstuk een fiscaal en een bedrijfseconomisch aspect heeft. Door de vaagheid van de term "aspect" is het niet mogelijk dit gestelde af te wijzen. Wel is het noodzakelijk vast te stellen, dat het aan de orde gestelde vraagstuk een bedrijfseconomisch vraagstuk is. Het moge dan een fiscaal aspect hebben, de motivering van de conclusie in het probleem zal een bedrijfseconomische moeten zijn. Van het fiscale aspect is zeker niet relevant, dat de vennootschapsbelasting naar de gebruikelijke onderscheiding niet tot de kostprijsverhogende belastingen wordt gerekend. Wel van belang kan worden geacht de vraag of en in welke mate de vennootschapsbelasting wordt afgewenteld via de prijsvorming van het product van de belastingplichtige.

Het lijkt aannemelijk, dat de druk van een belasting, geheven over een kostenfactor eerder wordt overgedragen en mogelijk vollediger tot overdracht komt, dan een belasting, geheven van de ondernemerspremie. Deze toch heeft in zo sterke mate het karakter van een ,,rent" dat overdracht van belastingdruk belangrijk minder voor de hand ligt. Het komt mij voor, dat de beschouwing van het bedrijfseconomische vraagstuk wel van waarde moet zijn voor de behandeling van een fiscaal probleem op het gebied van de overdracht van belastingen.

Maar Brugge acht het door hem onderkende fiscale aspect, dat de vennootschapsbelasting kan worden gezien als een ,,voorheffing” op de inkomstenbelasting, van bepalende betekenis. Vennootschapsbelasting èn inkomstenbelasting moeten tezamen worden beschouwd als één stelsel van belastingheffing naar het inkomen, zo zegt hij. Hier is toch geen sprake van een zodanige evidentie, dat van een motivering voor deze stelling zou kunnen worden afgezien. Formeel is

$\mathrm{mab}$ blz. 76 
er van voorheffing in het geheel geen sprake. Ook materieel meen ik, dat van een effect als van een voorheffing niet blijkt. Wanneer op de vermogensmarkt het rendement van aandelen (dan wel preferente aandelen) wordt vergeleken met dat van obligaties wordt toch geen verschil in aanmerking genomen, afkomstig van de gestelde ,voorheffing"?

Zeker zijn er gevallen, waarin voor een N.V. en haar aandeelhouders de som van vennootschapsbelasting en inkomstenbelasting kleiner is, dan de inkomstenbelasting alleen zou zijn geweest wanneer de aandeelhouders als natuurlijke personen zouden zijn aangeslagen voor de bedrijfswinst. Maar is die omstandigheid nu van zo grote betekenis voor het onderhavige vraagstuk, dat het daardoor vrijwel geheel zou zijn bepaald?

Het genoemde fiscale alternatief ligt er toch alleen wanneer de rechtsvorm van het bedrijf, op grond van de door die rechtsvorm te vervullen behoeften, niet die van de rechtspersoon behoeft te zijn. Ofschoon het aantal van de bedrijven, waarvoor dit (nog) geldt, mogelijk aanzienlijk is, moet in aanmerking worden genomen, dat hun gezamenlijke omvang b.v. gemeten naar het aangewende vermogen als kleiner moet worden aangezien dan van degenen, waarvoor dit alternatief niet geldt. Daarbij moet worden bedacht, dat voor de z.g. „open” vennootschap het aangeduide alternatief niet bestaat, noch voor de „,besloten” vennootschap, wier aandeelhouders belastbaar zijn naar een zodanig inkomen, dat door de N.V.-vorm geen degressie van het inkomstenbelastingtarief ontstaat, zomin als voor de "besloten” vennootschap, die de andere, vaak zo bijzonder belangrijke, gevolgen van de rechtspersoonlijkheid van de onderneming niet kan missen.

Hetgeen Brugge opmerkt over de ook bij de rente van vreemd vermogen voorkomende dubbele belastbaarheid, in het bijzonder bij de banken, acht ik onjuist. Die rente, voorzover bij de bank met vennootschapsbelasting belast, is daar hetzij rente van eigen vermogen, dan wel ondernemerspremie; geheel zoals dat ook bij de andere aan de vennootschapsbelasting onderworpen lichamen het geval is.

De bedrijfseconomische overwegingen van Brugge kunnen doelmatig worden besproken tezamen met die van Kramers. De vraag, zoals ze door beiden wordt benaderd is deze: welke invloed heeft de conclusie over het vraagstuk in onderzoek voor de doelmatigheid van de kostprijs als instrument voor de leiding. De uitroep: „zou de vennootschapsbelasting wel kostenfactor zijn, dan zou dit betekenen, dat het juridische kleed, waarin het bedrijf is gehuld, invloed uitoefent op de kostprijs en dus op de ondernemerspremie" bevat duidelijk geen enkel argument. Zij geeft slechts een gevolg aan van de gestelde conclusie.

De verhoging van de kosten door de heffing van vennootschapsbelasting over schijnwinsten, zoals in het geval van afschrijvingen op duurzame productiemiddelen, is ook zo een gevolg van de gestelde conclusie ${ }^{1}$ ). In het proefschrift van Dr. A. C. J. Nouwens ,Beschouwingen ten aanzien van de overdracht van belastingen" (1956) wordt dit oordeel reeds gegeven en samengevat in de stelling (blz. 111), dat een belasting op schijnwinsten in wezen een kostprijsverhogende belasting betekent.

De auteurs Brugge en Kramers zien in het opnemen van de vennootschapsbe-

1) Voor het vraagstuk van de betekenis van de belasting over schijnwinsten wordt mede verwezen naar het proefschrift (1961) van Dr. W. L. G. S. Hoefnagels: „De invloed van fiscale afschrijvingen en investeringsaftrek op financiering, rentabiliteit en kostprijs".

m a b blz. 77 
lasting over de rente van het doelmatig aangewende eigen vermogen in de kostprijs slechts nadelen voor dit instrument van de leiding. Op de door mij gegeven motieven, waarom de zo berekende kostprijs beter aan zijn doelstellingen beantwoordt, gaan zij niet in. Zowel voor de functie van de kostprijs als uitgangspunt voor de bepaling van de aanbiedingsprijs, als voor de beoordeling van de winstgevendheid van alternatieve producten heb ik geargumenteerd, dat de kostprijsberekening zonder vennootschapsbelasting niet zou kunnen voldoen.

Reeds voor de alternatieve keuze van aanwending van eigen vermogen in het eigen bedrijf, dan wel in de risicodragende sfeer in een ander bedrijf, moet naar mijn oordeel gecalculeerd worden met de vennootschapsbelasting over de rente van het in eigen bedrijf aangewende vermogen. Buiten het eigen bedrijf kan n.l. tegen de geldende rentabiliteitsvoet voor gewone aandelen het eigen vermogen vrij van vennootschapsbelasting worden aangewend, door de deelnemingsvrijstelling resp. die van de effectenbeleggingsmaatschappij. Zo de aanwending in eigen bedrijf na vennootschapsbelasting duurzaam niet ten minste gelijk is an genoemde rentabiliteitsvoet, is de keuze fout geweest.

Gaat men bij de calculatie ter voorbereiding van de beleidsbeslissing te werk met de rente van het eigen vermogen zònder vennootschapsbelasting, dan kan de keuze niet doelmatig op die calculatie worden gebaseerd.

Hier vind ik nu gelegenheid om in te gaan op de conclusie, die Foppe in zijn artikel bereikt. Ik haal die conclusie daarom eerst als volgt aan:

„dat bij de calculatie met de „rente” over eigen vermogen, maar ook met de daardoor veroorzaakte belasting moet worden rekening gehouden, waarbij men zich zal dienen te beperken tot het dividend, dat de vermogensverschaffer eist om pariwaarde van zijn aandeel te wettigen, alsmede de over dit dividend verschuldigde belasting, die men als verlengstuk van het primaire dividend moet zien".

Deze conclusie beantwoordt de door mij aan de orde gestelde vraag in dezelfde zin als ik dat deed, maar zij bevat een aanzienlijke restrictie: die tot de rente over het nominale kapitaal.

In de motivering werkt Foppe met de omstandigheden van de oprichters van een nieuwe naamloze vennootschap. Zo die omstandigheden toelaten de conclusie te bereiken, zij steunen de gestelde restrictie onvoldoende. Bij die nieuwe naamloze vennootschap zijn nominaal kapitaal en eigen vermogen nog gelijk of nagenoeg gelijk. Over het belangrijke verschil tussen mijn conclusie en de zijne zegt de motivering van Foppe dan ook niets.

Zou het doelmatig zijn in de berekening van de rente van het eigen vermogen de vennootschapsbelasting slechts mee te rekenen op basis van het nominaal kapitaal? Om die vraag te onderzoeken, zou men te werk gaande zoals Foppe, zich moeten afvragen of een naamloze vennootschap, welker eigen vermogen (aanzienlijk) afwijkt van haar nominaal kapitaal een dividend zal hebben uit te keren, dat de vermogensverschaffer eist om pariwaarde van zijn aandeel te wettigen. Het spreekt geheel vanzelf, dat dat dividend dan heel wat hoger zal zijn; de facto zal moeten zijn. En op grond daarvan zou Foppe tot een andere conclusie moeten komen, die zoal niet gelijk aan de mijne daar dan toch veel dichter bij zou moeten liggen.

Overigens ben ik niet van oordeel, dat het nominaal kapitaal hier een doel- 
matig gegeven kan opleveren, zomin als ik meen, dat het gedeclareerde dividend een bepalende rol in dit vraagstuk speelt. Beide kunnen duurzaam zo zeer afwijken van het eigen vermogen resp. de rente over dat eigen vermogen, en de oorzaken van die afwijkingen kunnen en zullen doorgaans zo verscheiden zijn, dat op deze grondslag geen voor de beleidsbeslissingen doelmatige calculatie kan worden gebaseerd.

Opmerkelijk is, dat Foppe evenals Kramers in zijn beschouwingen over de rentekosten in de kostprijsberekening uitsluitend spreekt over een niet gedifferentieerde rentefactor voor alle vermogensaanwending. Ofschoon ook ik van oordeel ben, dat het verband tussen vermogen en vermogensaanwending naar de structurele samenhang moet worden gelegd en bij bedrijven met een enkelvoudig structuurpatroon voor verbijzondering van de rentekosten naar de verschillende rentetarieven geen plaats is en ook geen behoefte bestaat, onder ogen moet worden gezien, dat daar in andere omstandigheden wel aanleiding toe kan zijn.

Het hiervoor genoemde alternatief van aanwending van eigen vermogen was daarvan al een voorbeeld.

In het algemeen zal in de beleidsbeslissing in het kader van de expansie van het bedrijf, wanneer het dus gaat om de alternatieve mogelijkheden der expansie, een zodanige verbijzondering wel mogelijk zijn en ook noodzakelijk in alle gevallen, waarin het kostenverschil relatief groot kan zijn. Met name kan dit het geval zijn, indien alternatieve plannen in een verschillende mate met eigen vermogen moeten worden gefinancierd, hetzij op grond van verschil in verdeling van de aanwendingsduren dan wel door een verschil in risicodracht, zoals b.v. ten gevolge van een groter prijsrisico. Ik acht die risicodracht mede bepalend voor de keuze der vermogenssoort, niet voor de hoogte van het rentepercentage. De calculatie beperke zich tot het ,rente"-element.

Zien we voorts nog eens naar enkele andere toepassingen van de kostprijsberekening. Ik heb destijds al genoemd: verschillend product voortgebracht met relatief verschillend vermogensbeslag. In de kostprijs is de rentefactor dus relatief verschillend. $\mathrm{Bij}$ de beoordeling van de opbrengstprijzen resp. de relatieve winstgevendheid der verschillende producten, wordt een verschillende uitkomst verkregen, afhankelijk van het al of niet incalculeren van vennootschapsbelasting over de rente over het eigen vermogen. Wordt dienovereenkomstig verschillend beslist, dan zal degene, die inclusief vennootschapsbelasting calculeerde, een betere uitkomst krijgen.

Hierin moet men niet zien een aanpassen van de kostprijstheorie aan het bedrijfseconomisch onjuist zijn van de fiscale inkomensbepaling, zoals Kramers meent. Voor de bedrijfseconomie behoort de belastingheffing tot de data. Het is aan haar om binnen haar doelstellingen in haar normatieve conclusies met de gevolgen der belastingheffing rekening te houden.

Hier mag nog wel aanvullend genoemd worden de z.g. diepte-investering. $Z_{i j}$ moet worden gekozen op grond van de daarmee te verkrijgen kostprijsverlaging. Hoe wordt deze nu doelmatig berekend? Door middel van een vergelijking van kostprijzen exclusief de vennootschapsbelasting over de rente van het aan te wenden vermogen, voor zover dat eigen vermogen moet zijn, wordt een onjuiste uitkomst verkregen. Er wordt reeds een voordelig kostprijsverschil aan de investering toegeschreven alvorens het aangewende eigen vermogen het ter vermogensmarkt geldende rendement opbrengt.

m a b blz. 79 
Zoals in de aanhef van dit artikel is gezegd, moet nog op één opmerking, en wel van Kramers, worden ingegaan. Wat is op grond van de gegeven overwegingen de invloed op de kostprijs van de inkomstenbelasting over de rente van het eigen vermogen voor een aan de inkomstenbelasting onderworpen producent, gezien het progressieve tarief? Ogenschijnlijk ligt er een bijzondere moeilijkheid in het tarief. Toch geloof ik, dat dat minder het geval is, dan het lijkt. Ik meen te mogen stellen, dat de genoemde situatie slechts behoeft te worden bezien ten aanzien van de natuurlijke persoon.

Het eigen vermogen is dan het vermogen van die natuurlijke persoon of personen, geheel en niet meer dan dat. De risicodracht, een der hoofdkenmerken van het eigen vermogen, strekt zich over alle eigen vermogen uit. Gezien het persoonlijke karakter van de inkomstenbelasting treft zij de opbrengst van het (eigen) vermogen van de natuurlijke persoon, ongeacht waarin dat vermogen zal zijn aangewend: in het bedrijf of niet in het bedrijf. De belastingheffing is dus niet specifiek voor de aanwending in het bedrijf. Behoudens de mogelijkheid uit beleidsoverwegingen een deel van het vermogen braak te laten liggen en van de rente-opbrengst af te zien, zal aanwending zowel in als buiten het bedrijf de rente-opbrengst doen genieten en doen belasten. Het alternatief van het onbelegd laten kan mij niet brengen tot de conclusie, dat de inkomstenbelasting specifiek verbonden is aan de vermogensaanwending in het bedrijf. Daarom zie ik daarin vooralsnog dan ook geen kostenfactor.

Ik zie ook niet, dat de investeringsbeslissing onjuist zou worden beïnvloed door nu geen belasting over de ingecalculeerde rente in aanmerking te nemen. Ook niet dat de beoordeling van de relatieve winstgevendheid van verschillende producten, die anders uitvalt dan bij de N.V., in dit geval onjuist zou worden. De belasting over de rente van het eigen vermogen is voor de natuurlijke persoon (een enkele uitzondering daargelaten) een gegeven grootheid, ongeacht de aanwending van dat vermogen in het eigen bedrijf.

Niet onvermeld mag daarom blijven, dat naar mijn mening de alleen-handelende en de firma zowel als de commanditaire vennootschap (niet op aandelen) voor de rente van het ,eigen" vermogen lagere kosten hebben dan de naamloze vennootschap, die het in eigen bedrijf aanwendt.

Tenslotte meen ik goed te doen nog op te merken, dat de voorgestane conclusie over het in dit stuk opnieuw aan de orde gestelde vraagstuk een wat ander oordeel toelaat over een verschijnsel, dat nu al een aantal jaren mijn aandacht had getrokken. Dat bestaat uit de omstandigheid, dat bij de berekeningen omtrent de investeringsalternatieven in de bedrijven de rentabiliteitsverhoudingen der proposities, die in de wedloop een plaats kunnen innemen, zo veel hoger zijn, dan voor een vermogenshuur, ook die met een risicofactor, zou mogen worden verwacht. Een geheel andere indruk geven zulke berekeningen, indien de belasting over de rente wordt meegerekend. De rentefactor (indien uitsluitend eigen vermogen in aanmerking komt) verdubbelt vrijwel $\left.{ }^{2}\right)^{3}$ ). De gecalculeerde grootte van de te verwachten premie is dienovereenkomstig kleiner. In het bijzonder wordt de verhouding van de gecalculeerde premie tot de gecalculeerde rente kleiner en meestal veel kleiner.

$\left.{ }^{2}\right)$ Vgl. Stichting voor Economisch onderzoek van de Universiteit van Amsterdam 1960: Het vaststellen van investeringsprioriteiten pag. 92/93 en 140 .

3) De veronderstelling van De Koning, dat ik sprekende over het enorme kostenverschil van het eigen vermogen ten opzichte van het vreemde, een verschil in offers en niet een verschil in kosten op het oog zou hebben, is niet juist. De tekst (M.A.B. 1959 pag. 427) geeft zelfs naar mijn oordeel geen aanleiding tot die veronderstelling.

$\mathrm{m}$ a b blz. 80 